\title{
Effect of Partial Gastrectomy on Pulmonary Physiology
}

\author{
K. N. V. PALMER,* M.A., M.D., M.R.C.P. ; A. J. S. GARDINER, † M.B., CH.B. \\ With the Technical Assistance of Miss M. H. McGREGOR, M.s.c.T.
}

Brit. med. F., 1964, 1, 347-349

An upper abdominal operation has a profound effect on pulmonary mechanical function. This effect occurs in those who do not develop atelectasis, but patients with atelectasis show a greater and more persistent impairment of ventilatory function and, unlike normals, often develop reversible airways obstruction during the first three post-operative days as shown by increases in the peak expiratory flow rate after the inhalation of a bronchodilator drug (Palmer, 1961). We have investigated the effect of a major upper abdominal operation - partial gastrectomy - on ventilatory function, arterial bloodgas levels, and the acid-base balance.

\section{Methods}

Thirty-two patients were studied, all of whom had been admitted to a surgical unit for elective surgery for chronic peptic ulcer. A standard anaesthetic technique was used, the patients being paralysed and artificially ventilated with a Blease pulmoflater. Measurements were made before the operation and at daily intervals for five days afterwards. Ventilatory function was studied by measuring tidal volume (Vt), minute ventilation ( $\mathrm{Vm}$ ), vital capacity (V.C.), forced expiratory volume in $1 \mathrm{sec}$. (F.E.V., ), and expiratory reserve volume (E.R.V.) with a low-resistance water-sealed spirometer with variable drum speeds. All the measurements were made with the patients semi-recumbent. Three spiro- constructed for each patient. Arterial oxygen tensions $\left(\mathrm{Po}_{2} \mathrm{~mm} . \mathrm{Hg}\right)$ were derived by interpolation in the dissociation curves of Dill and Forbes (1941) with correction for $p \mathrm{H}$ and temperature. Arterial whole-blood carbon dioxide content (T. $\mathrm{CO}_{2} \mathrm{mM} / \mathrm{l}$.) was measured with a Van Slyke manometric apparatus, and the $\mathrm{pH}$ of the arterial blood was measured with a capillary glass electrode system reading to $0.005 \mathrm{pH}$ unit. After the haematocrit had been measured, the arterial $\mathrm{PCO}_{2}$, the plasma bicarbonate $\left(\mathrm{HCO}_{3}{ }^{-}\right) \mathrm{p}$, and whole-blood buffer base were derived from the nomogram of Singer and Hastings (1948). Portable chest radiographs were taken before the operation and at daily intervals afterwards for five days. Throughout the period of the experiment the usual routine treatment for the prevention of atelectasis was given. This consisted of physiotherapy and assisted coughing. Where atelectasis developed, mucolytics, intensive bronchodilator therapy, and antibiotics were also given.

\section{Results}

For analysis the patients are separated into two main groups as follows :

Group $A$ is the normal or uncomplicated group in which there were 14 patients ( 11 men and 3 women). The mean age was 47.8 years. Seven were cigarette smokers, and $5(35.5 \%)$ smoked 20 or

TABLE I.-Mean Ventilatory Function in 32 Patients Before and After Partial Gastrectomy (Measurements Expressed at Body Temperature and Pressure Saturated with Water Vapour)

\begin{tabular}{|c|c|c|c|c|c|c|c|c|c|c|c|c|c|c|c|c|c|c|c|c|c|}
\hline & & \multicolumn{10}{|c|}{ Group A (14 Normals) } & \multicolumn{10}{|c|}{ Group B (18 Patients with Atelectasis) } \\
\hline & & \multicolumn{2}{|c|}{ V.C. (ml.) } & \multicolumn{2}{|c|}{ F.E.V.1 (ml.) } & \multicolumn{2}{|c|}{ E.R.V. (ml.) } & \multicolumn{2}{|c|}{ Vt (ml.) } & \multicolumn{2}{|c|}{$\dot{V} \mathrm{~m}(1 . / \mathrm{min})}$. & \multicolumn{2}{|c|}{ V.C. (ml.) } & \multicolumn{2}{|c|}{ F.E.V.1 (ml.) } & \multicolumn{2}{|c|}{ E.R.V. (ml.) } & \multicolumn{2}{|c|}{$\mathrm{Vt}(\mathrm{ml})}$. & \multicolumn{2}{|c|}{$\operatorname{Vm}(1 . / \mathrm{min})}$. \\
\hline & & $\mathbf{a}$ & $\mathbf{b}$ & a & b & $\mathbf{a}$ & $\mathbf{b}$ & $\mathbf{a}$ & $\mathbf{b}$ & $\mathbf{a}$ & $\mathbf{b}$ & $\mathbf{a}$ & b & a & $\mathbf{b}$ & $\mathbf{a}$ & b & $\mathbf{a}$ & $\mathbf{b}$ & $\mathbf{a}$ & $\mathbf{b}$ \\
\hline $\begin{array}{l}\text { Before operation } \\
\text { Days after } \\
\text { operation }\end{array}$ & $\left\{\begin{array}{l}1 \\
2 \\
3 \\
4 \\
5\end{array}\right.$ & $\begin{array}{l}3,963 \\
1,765 \\
2,136 \\
2,619 \\
2,846 \\
2,999\end{array}$ & $\begin{array}{l}3.946 \\
1,790 \\
2,172 \\
2,555 \\
2,897 \\
3,058\end{array}$ & $\begin{array}{l}3,170 \\
1,509 \\
1,893 \\
2,276 \\
2,428 \\
2,699\end{array}$ & $\begin{array}{l}3,137 \\
1,543 \\
1,901 \\
2,290 \\
2,466 \\
2,728\end{array}$ & $\begin{array}{r}1,107 \\
459 \\
535 \\
706 \\
783 \\
743\end{array}$ & $\begin{array}{l}930 \\
493 \\
612 \\
686 \\
730 \\
760\end{array}$ & $\begin{array}{l}779 \\
619 \\
644 \\
699 \\
739 \\
761\end{array}$ & $\begin{array}{l}814 \\
652 \\
686 \\
728 \\
780 \\
830\end{array}$ & $\begin{array}{l}10 \cdot 49 \\
13 \cdot 10 \\
12 \cdot 34 \\
12 \cdot 87 \\
12 \cdot 69 \\
12 \cdot 75\end{array}$ & $\begin{array}{l}13.07 \\
16.73 \\
14 \cdot 88 \\
14.48 \\
14.99 \\
15 \cdot 12\end{array}$ & $\begin{array}{l}3,744 \\
1,487 \\
1,883 \\
2,278 \\
2,531 \\
2,657\end{array}$ & $\begin{array}{l}3,717 \\
1,579 \\
1,854 \\
2,276 \\
2,531 \\
2,693\end{array}$ & $\begin{array}{l}3,035 \\
1,238 \\
1,572 \\
1,848 \\
2,223 \\
2,591\end{array}$ & $\begin{array}{l}3,105 \\
1,348 \\
1,688 \\
2,008 \\
2,222 \\
2,444\end{array}$ & $\begin{array}{l}858 \\
363 \\
520 \\
562 \\
706 \\
666\end{array}$ & $\begin{array}{l}842 \\
378 \\
449 \\
580 \\
678 \\
712\end{array}$ & $\begin{array}{l}874 \\
581 \\
645 \\
724 \\
731 \\
725\end{array}$ & $\begin{array}{l}847 \\
669 \\
700 \\
735 \\
774 \\
850\end{array}$ & $\begin{array}{l}12.72 \\
12.89 \\
12.32 \\
13.22 \\
13.40 \\
13.26\end{array}$ & $\begin{array}{l}14.06 \\
14.15 \\
13.40 \\
14.67 \\
14.96 \\
16.84\end{array}$ \\
\hline
\end{tabular}

grams were recorded before and three after the inhalation of $1 \mathrm{ml}$. of $1 \%$ isoprenaline, the highest value in each instance being taken. Spirometric measurements are expressed at body temperature and pressure saturated with water vapour.

Arterial blood samples were obtained before spirometry, from the brachial or femoral artery in a 10-ml. heparinlubricated Luer-lok syringe. The blood was allowed to fill the syringe under its own pressure during one to two minutes. During this period the patient was encouraged to relax and breathe naturally. The following analyses were carried out as soon as possible afterwards.

The percentage arterial oxygen saturation $\left(\mathrm{SO}_{2} \%\right)$ was determined by a photoelectric technique of reflection oximetry using a Brinkman haemoreflector, calibration curves being

* Senior Lecturer, Department of Medicine, University of Aberdeen. t Clinical Research Fellow, Department of Medicine, University of Aberdeen. more a day. Three $(21.4 \%)$ were bronchitic, bronchitis being defined as a productive cough occurring on most days for three months in the year during at least two years (Ciba Symposium, 1959).

Group $B$ is the complicated groun who developed clinical and radiological evidence of atelectasis. There were 18 patients in this group ( 15 men and 3 women). The mean age was 46.0 years. Fourteen were cigarette smokers, and $10(55.6 \%)$ smoked 20 or over a day. Twelve $(66.6 \%)$ were bronchitic as defined above.

Seven patients in group B developed a severe pulmonary complication with atelectasis, leading to bronchopneumonia and fever with much cough and purulent sputum. All were male, the mean age was 43.1 years, all smoked over 20 cigarettes a day, and all gave a history of persistent productive cough, wheezing, dyspnoea on exertion, and there were rhonchi on physical examination, so that in this group there was bronchitis with airways obstruction. The remaining 11, although there was definite clinical and radiological evidence of atelectasis, did not develop bronchopneumonia. 
Table I shows the results of the measurements of ventilatory function in the two groups. In both groups the preoperative values for V.C. were within the predicted range in all the patients according to the formula of Baldwin et al. (1948), the normal range being equal to the predicted value $\pm 20 \%$ of the predicted value.

In group $B$ patients there was a slight mean increase in F.E.V. ${ }_{1}$ after the bronchodilator before the operation, indicating some reversible airways obstruction, and this was especially noticeable in those who later developed severe postoperative complications.

After the operation there was a considerable reduction in V.C. in both groups, maximal on the first post-operative day, the values increasing each day afterwards, although in neither group had the pre-operation value been regained by the fifth post-operative day. In group B the reduction in V.C. was more pronounced and more persistent. While there was no significant increase in V.C. after the bronchodilator in group $A$, there was an increase in group $B$ on the first post-operative day. The changes in F.E.V. ${ }_{1}$ were similar to those in V.C., the reduction being maximal on the first post-operative day and gradually becoming less marked afterwards. In group B, however, the reduction in F.E.V..$_{1}$ was greater and there was a mean increase of $128 \mathrm{ml}$. (10.5\%) after the bronchodilator during the first three post-operative days. These changes were more striking in the severely complicated group, when a mean increase in F.E.V. ${ }_{1}$ after the bronchodilator of $175 \mathrm{ml}$. (14.3\%) during the first three post-operative days was found. The E.R.V. was much reduced in both groups, especially during the first three post-operative days.

The tidal volume was reduced from the pre-operative values in the early post-operative period in both groups, but the respiratory rate was raised and the minute-ventilation was thereby increased. In both groups the minute-ventilation increased after isoprenaline.

\section{Arterial Blood-Gas Levels (Table II)}

In the normals there was a slight degree of post-operative hypoxaemia, which persisted for five days. In cases of atelectasis, hypoxaemia was more marked, and in the seven coses that developed a severe post-operative pulmonary complication desaturation was even more striking, especially on the second post-operative day (mean $\mathrm{So}_{2} 88.5 \%$, mean $\mathrm{PaO}_{2}$ $59.6 \mathrm{~mm}$. $\mathrm{Hg}$ ). There was no evidence of hypercapnia in either group-in fact, there was a tendency towards hypocapnia presumably due to hyperventilation, and this was especially so in the severely complicated group on the fourth and fifth post-operative days (mean arterial $\mathrm{PCO}_{2} 26.1 \mathrm{~mm}$. $\mathrm{Hg}$ ). The effect of breathing $30 \% \quad \mathrm{O}_{2}$ on the $\mathrm{SO}_{2} \%$ was

TABLE II.-Arterial Blood-gas Loools

\begin{tabular}{|c|c|c|c|c|c|c|}
\hline & \multicolumn{3}{|c|}{ Group A (14 Normals) } & \multicolumn{3}{|c|}{$\begin{array}{l}\text { Group B (18 Patients } \\
\text { with Atelectasis) }\end{array}$} \\
\hline & $\begin{array}{l}\text { Mean } \\
\mathrm{PcO}_{\mathbf{g}} \\
(\mathrm{mm} . \\
\mathrm{Hg})\end{array}$ & $\begin{array}{c}\text { J lean } \\
\text { O }_{2} \text { Sat. } \\
(\%)\end{array}$ & $\begin{array}{c}\text { Mean } \\
\mathrm{Po}_{\mathbf{2}} \\
(\mathrm{mm} . \\
\mathrm{Hg} \text { by } \\
\text { Interpo- } \\
\text { lation) }\end{array}$ & $\begin{array}{l}\text { Mean } \\
\mathrm{PCO}_{\mathbf{g}} \\
(\mathrm{mm} . \\
\mathrm{Hg})\end{array}$ & $\begin{array}{c}\text { Mean } \\
\text { O }_{2} \text { Sat. } \\
(\%)\end{array}$ & $\begin{array}{c}\text { Mean } \\
\text { Po }_{2} \\
\text { (mm. } \\
\text { Hg by } \\
\text { Interpo- } \\
\text { lation) }\end{array}$ \\
\hline Before operation $\left\{\begin{array}{l}\text { Days after operation }\{ \\
3 \\
5\end{array}\right.$ & $\begin{array}{l}38 \cdot 3 \\
36 \cdot 6 \\
35 \cdot 5 \\
35 \cdot 6 \\
37 \cdot 2 \\
37 \cdot 0\end{array}$ & $\begin{array}{l}96 \cdot 4 \\
95 \cdot 0 \\
94.8 \\
95 \cdot 6 \\
94 \cdot 8 \\
95 \cdot 6\end{array}$ & $\begin{array}{l}89 \cdot 3 \\
76 \cdot 5 \\
74 \cdot 6 \\
79 \cdot 9 \\
73 \cdot 3 \\
76 \cdot 7\end{array}$ & $\begin{array}{l}39 \cdot 4 \\
36 \cdot 5 \\
36 \cdot 4 \\
35 \cdot 3 \\
31 \cdot 0 \\
30 \cdot 9\end{array}$ & $\begin{array}{l}96 \cdot 5 \\
92 \cdot 3 \\
90 \cdot 9 \\
91 \cdot 5 \\
93 \cdot 4 \\
94 \cdot 2\end{array}$ & $\begin{array}{l}90 \cdot 1 \\
66 \cdot 6 \\
63 \cdot 3 \\
67 \cdot 1 \\
71 \cdot 0 \\
73 \cdot 0\end{array}$ \\
\hline
\end{tabular}

studied by obtaining serial samples of arterial blood from an in-dwelling Riley needle in two normals and two cases of atelectasis in the first three post-operative days. In the normals the arterial $\mathrm{O}_{2}$ saturation rapidly reached normal, but in the atelectasis cases, although the $\mathrm{So}_{2} \%$ rose, it did not reach normal levels (Table III).
TABLE III.-Effect of Breathing $30 \% \mathrm{O}_{2}$ on Oxygen Saturation of Arterial Blood Post-operatively

\begin{tabular}{|c|c|c|c|c|c|c|c|}
\hline \multirow{2}{*}{ Case } & \multirow{2}{*}{\multicolumn{3}{|c|}{ Day }} & \multirow{2}{*}{$\begin{array}{c}\text { Arterial } \\
\mathrm{So}_{2} \% \\
\text { before } \\
\mathrm{O}_{2}\end{array}$} & \multicolumn{3}{|c|}{ While Breathing $30 \% \mathrm{O}_{2}$} \\
\hline & & & & & 5 mins. & 10 mins. & 15 mins. \\
\hline 2 & $\begin{array}{l}\text { 1st post-op. } \\
\text { 2nd post-op. } \\
\text { 3rd post-op. } \\
\text { 1st post-op. } \\
\text { 2nd post-op. } \\
\text { 3rd post-op. }\end{array}$ & $\begin{array}{l}\ddot{*} \\
\ddot{0} \\
\ddot{0}\end{array}$ & 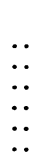 & $\begin{array}{l}\text { Normal Cas } \\
95 \cdot 5 \% \\
95.5 \% \\
96 \% \\
92 \% \\
92 \% \\
94 \%\end{array}$ & $\begin{array}{l}\mathbf{9 7} \% \\
97 \% \\
97 \% \\
98 \% \\
98 \% \\
98 \%\end{array}$ & $\begin{array}{l}97 \% \\
97 \% \\
97 \% \\
98 \% \\
98 \% \\
98 \%\end{array}$ & $\begin{array}{l}97 \% \\
97 \% \\
97 \% \\
98 \% \\
98 \% \\
98 \%\end{array}$ \\
\hline $\begin{array}{l}\text { I } \\
\text { II }\end{array}$ & $\begin{array}{l}\text { 1st post-op. } \\
\text { 2nd post-op. } \\
\text { 3rd post-op. } \\
\text { 18t post-op. } \\
\text { 2nd post-op. } \\
\text { 3rd post-op. }\end{array}$ & $\begin{array}{l}\ddot{.} \\
\ddot{0} \\
\ddot{\ldots}\end{array}$ & $\begin{array}{l}\ldots \\
\because \\
\because \\
\cdots\end{array}$ & $\begin{array}{l}\text { Atelectasis C } \\
\mathbf{8 9} \% \\
83.5 \% \\
88 \% \\
90 \% \\
85 \% \\
88 \%\end{array}$ & $\begin{array}{l}\text { ises } \\
91 \% \\
90 \% \\
91 \% \\
91 \% \\
88 \% \\
90 \%\end{array}$ & $\begin{array}{l}91 \% \\
91 \% \\
92 \% \\
92 \% \\
90 \% \\
91 \%\end{array}$ & $\begin{array}{l}93 \% \\
92 \% \\
94 \% \\
92 \% \\
90 \% \\
91 \%\end{array}$ \\
\hline
\end{tabular}

\section{Acid-Base Balance (Table IV)}

The mean arterial blood $p H$ was well within the normal range in both groups, and did not change appreciably after the operation. There was a slight fall from the pre-operative levels in mean $\left(\mathrm{HCO}_{3}^{-}\right) \mathrm{p}$, mean arterial $\mathrm{TCO}_{2}$, and mean buffer-base after the operation in both groups, and this was most marked in the complicated group, especially on the fourth and fifth post-operative days.

TABLE IV.-Acid-base Balance

\begin{tabular}{|c|c|c|c|c|c|c|c|c|}
\hline & \multicolumn{4}{|c|}{ Group A (14 Normals) } & \multicolumn{4}{|c|}{$\begin{array}{c}\text { Group B (18 Patients with } \\
\text { Atelectasis) }\end{array}$} \\
\hline & $\underset{p \mathrm{H}}{\operatorname{Mean}}$ & $\begin{array}{c}\text { Mean } \\
\left(\mathrm{HCO}_{\mathrm{s}}^{-}\right) \mathrm{p} \\
\mathrm{mEq} / 1 .\end{array}$ & $\begin{array}{l}\text { Mean } \\
\text { T.CO } \\
\text { mM/1. }\end{array}$ & $\mid \begin{array}{c}\text { Mean } \\
\text { Buffer } \\
\text { Base } \\
\text { mEq/l. }\end{array}$ & $\underset{p \mathrm{H}}{\text { Mean }}$ & $\begin{array}{c}\text { Mean } \\
\left(\mathrm{HCO}_{3}^{-}\right) \mathrm{p} \\
\mathrm{mEq}^{-1} .\end{array}$ & $\begin{array}{l}\text { Mean } \\
\mathrm{T} . \mathrm{CO}_{2} \\
\mathrm{mM} / \mathrm{l} .\end{array}$ & $\begin{array}{c}\text { Mean } \\
\text { Buffer } \\
\text { Base } \\
\text { mEq/1. }\end{array}$ \\
\hline $\begin{array}{l}\text { Before opera- } \\
\text { tion } \\
\text { Days } \\
\text { after } \\
\text { opera- } \\
\text { tion }\end{array} \quad\left\{\begin{array}{l}1 \\
2 \\
3 \\
4 \\
5\end{array}\right.$ & $\begin{array}{l}7 \cdot 44 \\
7 \cdot 44 \\
7 \cdot 45 \\
7 \cdot 46 \\
7 \cdot 45 \\
7 \cdot 41\end{array}$ & $\begin{array}{l}24 \cdot 2 \\
23 \cdot 1 \\
23 \cdot 3 \\
23 \cdot 2 \\
23 \cdot 5 \\
23 \cdot 1\end{array}$ & $\begin{array}{l}22 \cdot 0 \\
19 \cdot 9 \\
20 \cdot 1 \\
20 \cdot 3 \\
20 \cdot 7 \\
21 \cdot 0\end{array}$ & $\begin{array}{l}48 \cdot 0 \\
48 \cdot 0 \\
47 \cdot 7 \\
47 \cdot 5 \\
47 \cdot 0 \\
46 \cdot 0\end{array}$ & $\begin{array}{l}7 \cdot 46 \\
7 \cdot 41 \\
7 \cdot 43 \\
7 \cdot 43 \\
7 \cdot 42 \\
7 \cdot 43\end{array}$ & $\begin{array}{l}25 \cdot 0 \\
23 \cdot 1 \\
23 \cdot 6 \\
23 \cdot 3 \\
22 \cdot 8 \\
22 \cdot 9\end{array}$ & $\begin{array}{l}21 \cdot 8 \\
20 \cdot 7 \\
20 \cdot 7 \\
20 \cdot 6 \\
20 \cdot 1 \\
20 \cdot 4\end{array}$ & $\begin{array}{l}48 \cdot 0 \\
45 \cdot 6 \\
46 \cdot 6 \\
47 \cdot 0 \\
46 \cdot 0 \\
45 \cdot 6\end{array}$ \\
\hline
\end{tabular}

\section{Discussion}

The only important difference between those who developed chest complications and those who did not was the higher incidence of heavy cigarette-smoking and bronchitis in the complicated group. In both groups pulmonary mechanical function was much reduced after the operation, and breathing was shallow, rapid, and predominantly in the expiratory position. The impairment of ventilatory function was of restrictive type in both groups, but the complicated group in addition showed reversible airways obstruction during the first three post-operative days. In both groups the minuteventilation increased after the inhalation of isoprenaline. The reason for this is not clear, but we have observed the same effect in patients having isoprenaline for bronchial asthma, and it is possible that isoprenaline may stimulate respiration directly.

Arterial desaturation has been found immediately after minor operations under general anaesthesia (Nunn and Payne, 1962), but we found in the present series a significant degree of hypoxaemia persisting for at least five days after the operation, and this was most serious and most persistent in cases of atelectasis. It did not, however, strictly parallel the reduction in pulmonary mechanical function in either group, nor was it apparently due to overall hypoventilation, as there was no rise in arterial $\mathrm{CO}_{2}$ tension. The most likely explanation is that it results from regional alveolar hypoventilation and, in addition, in the complicated group to pulmonary capillary blood flow through unventilated atelectatic areas. 
We found that the post-operative hypoxaemia was rapidly reversed by breathing $30 \%$ oxygen in normals, but that in the atelectasis cases, although there was an increase in arterial oxygen saturation, it was not possible to achieve normal saturation and the rise was much slower. This is because, although $30 \%$ oxygen will raise the alveolar $\mathrm{Po}_{2}$ in hypoventilated alveoli sufficiently to achieve normal saturation of the pulmonary capillary blood, it will not raise the saturation of blood flowing through unventilated atelectatic areas.

It is difficult to recognize hypoxaemia from the presence of cyanosis until the $\mathrm{O}_{2}$ saturation has fallen to about $80 \%$ (Comroe and Botelho, 1947), and as it may not be possible to measure the arterial oxygen saturation it is logical to administer oxygen routinely after the operation to those patients who are least able to withstand hypoxaemia-that is, those in the older age-groups and those who have evidence of respiratory, cardiac, or cerebrovascular disease. As $30 \%$ $\mathrm{O}_{2}$ will correct the hypoxaemia this concentration is preferable to $100 \% \mathrm{O}_{2}$ because when the alveoli contain a high proportion of absorbable gas atelectasis may be more apt to occur. When there is post-operative atelectasis, serious hypoxaemia occurs which is often unrecognized. Therefore, in addition to the treatment of this complication with physiotherapy, bronchodilators, antibiotics, and mucolytic agents, oxygen therapy should always be given.

Although pulmonary mechanical function was considerably impaired, respiratory acidosis (raised arterial $\mathrm{PCO}_{2}$ ) did not occur-instead the arterial $\mathrm{PCO}_{2}$ levels were slightly reduced. This tendency towards a mild respiratory alkalosis might result from anoxic stimulation of the carotid and aortic bodies, but this does not occur until the arterial $\mathrm{Po}_{2}$ falls to about $60 \mathrm{~mm} . \mathrm{Hg}$; moreover, the lowest arterial $\mathrm{PCO}_{2}$ readings did not occur on the days when the arterial $\mathrm{Po}_{2}$ was lowest. The arterial $\mathrm{PCO}_{2}$ levels, the whole-blood buffer base, $\left(\mathrm{HCO}_{3}{ }^{-}\right) \mathrm{p}$, and the arterial $\mathrm{T} . \mathrm{CO}_{2}$ appeared to be interrelated, as they were all most reduced on the same post-operative days, and it seems probable that the mild metabolic acidosis was secondary to hyperventilation.

\section{Summary}

The effect on pulmonary physiology of a major abdominal operation (partial gastrectomy) was studied in 32 patients by measuring ventilatory function, blood-gas levels, and the acid-base balance. Eighteen patients developed postoperative atelectasis-the only difference between these patients and those who did not develop pulmonary complications being that $66 \%$ were bronchitic compared with $21 \%$ of the uncomplicated group. The changes in pulmonary physiology were similar in both groups, but were in general more severe in the complicated group. There was marked restrictive ventilatory impairment, maximal on the first postoperative day, and the complicated group, in addition, showed reversible airways obstruction during the first three postoperative days. There was arterial hypoxaemia lasting at least five days, and this was more marked in the complicated group ; but in neither group did it strictly parallel the reduction in pulmonary mechanical function and it was thought to be due to regional alveolar hypoventilation. Hypercapnia did not occur, and the tendency to overventilation and hypocapnia was compensated for by the development of a mild postoperative metabolic acidosis.

Our thanks are due to Professor W. C. Wilson and the members of the department of surgery for their co-operation and for allowing us to examine their patients. We would also like to thank Professor H. A. F. Dudley for the stimulating interest he showed in these experiments. Our sincere thanks are also due to the Vaughan Hudson Clinical Trust and the Mary Kinross Clinical Trust for their generous help in the purchase of apparatus.

\section{REFERENCES}

Ciba Symposium (1959). Thorax, 14, 286.

Comroe, J. H., jun., and Botelho, S. (1947). Amer. F. med. Sa., 214, 1. Dill, D. B., and Forbes, W. H. (1941). Amer. 7. Physiol., 132, 685.

Nunn, J. F., and Payne, J. P. (1962). Lancet, 2, 631.

Palmer, K. N. V. (1961). Ibid., 1, 191.

Singer, R. B., and Hastings, A. B. (1948). Medicine (Baltimore), 27, 223.

\title{
Hypoxaemia After Crush Injury of the Chest
}

\author{
J. G. WHITWAM,* M.B., F.F.A. R.C.S. ; J. NORMAN, $†$ M.B., F.F.A. R.C.S.
}

Brit. med.F., 1964, 1, 349-351

It is often assumed that hypoxaemia following chest injury is due to inadequate alveolar ventilation and is therefore associated with carbon-dioxide retention. Harley (1961) and Barrett (1960) have discussed the factors which may cause hypoventilation in these patients. In addition, Harley (1961) has suggested that in patients with chest injury the pathological changes in the lung parenchyma may lead to a further reduction in the oxygenation of the arterial blood.

For many years oxygen therapy combined with measures to increase alveolar ventilation, such as clearing of secretions from the airways and relief of pulmonary tamponade, ${ }^{1}$ have been regarded as essential in the treatment of such patients. More recently, further procedures aimed at achieving adequate

\footnotetext{
* Senior Registrar, Department of Anaesthetics, The General Infirmary at Leeds.

$†$ Registrar, Department of Anaesthetics, The General Infirmary at Leeds.

"The term " pulmonary tamponade" refers to the reduction of total hung volume due to the presence of gas, fluid, or abdominal viscera in the pleural cavities.
}

alveolar ventilation have been advocated, such as tracheostomy and the use of intermittent positive-pressure respiration (I.P.P.R.) (Avery et al., 1956 ; Griffiths, 1960 ; Sellors, 1961).

Evidence is presented in this paper to show that when therapeutic measures result in adequate alveolar ventilation, as judged by the arterial carbon-dioxide tension $\left(\mathrm{P}_{\mathrm{a}} \mathrm{CO}_{2}\right)$, hypoxaemia, measured by percentage saturation of the arterial blood with oxygen $\left(\mathrm{S}_{\mathrm{a}} \mathrm{O}_{2}\right)$, may still be present. Some evidence is also presented regarding the probable cause of the arterial desaturation.

\section{Material}

Arterial blood-gas analyses have been performed on nine patients with crush injuries of the chest admitted to this centre.

Case 1.-Man aged 54. Multiple fractures of left ribs associated with paradoxical respiration. Other severe skeletal injuries. 